\title{
From a Horizontal Instrument to a Common European Sales Law
}

\author{
The Development of European Consumer and Market Law in 2011
}

\author{
Christoph Busch · Ronny Domröse
}

(C) Springer-Verlag 2012

In future issues of Euvr the legislation report will provide a short overview on new legislation and legislative proposals in the field of European Consumer and Market Law. Normally this report will be accompanied by an overview of cases pending at the Court of Justice of the European Union. The focus of the legislation report will be less on summarising the content but rather on commenting - although necessarily subjective - and the attempt to put the new legislation and cases into their respective context. The series starts with an overview of two prominent horizontal legislative texts: the new Directive on consumer rights and the planned Regulation on a Common European Sales Law. In addition, two texts regarding important sectoral issues are covered: the new Regulation on the provision of food information to consumers and the planned Directive on credit agreements relating to residential property.

\section{The directive on consumer rights: what remains from the planned horizontal instrument?}

In June 2011, the European Parliament gave its approval to the proposal for the Directive on consumer rights which had

Dr. Christoph Busch, Maître en Droit ( $₫)$

Senior Researcher at the European Legal Studies Institute, University of Osnabrück, Süsterstr. 28, 49069 Osnabrück, Germany e-mail: <Christoph.busch@uos.de>

\section{Ronny Domröse}

Senior Researcher at the Europa-University Viadrina Frankfurt (Oder), Große Scharrnstr. 59, 15230 Frankfurt (Oder), Germany

e-mail:<domroese@europa-uni.de> been revised several times before. ${ }^{1}$ The tenacious political struggle for the Directive has thus come to an end. Approval by the Council was given on 10.10.2011, interestingly just one day before the unveiling of the other major legislative project in the field of consumer contract law, the planned Regulation on a European Sales Law.

If one compares the final text ${ }^{2}$ of the Directive with the proposal submitted by the Commission in October $2008,{ }^{3}$ the outcome at first glance gives the impression of a failed legislative initiative. The Commission's proposal was the result of the so-called Acquis Review, a reform process initiated in 2004, ${ }^{4}$ which aimed at a fundamental restructuring of the Consumer Acquis. According to the Commission's plan, the new Directive should have served as a "horizontal instrument" providing a substantively and terminologically coherent foundation for European consumer law and be complemented by sector-specific ("vertical") legislative instruments. The horizontal instrument was meant to consolidate four directives: the Doorstep Selling Directive 87/577/EEC, the Unfair Terms Directive 93/13/EC, the Distance Selling Directive 97/7/EC and the Consumer Sales Directive 99/44/EC. In addition, the degree of harmonisation was to shift from minimum to full harmonisation. The final version of the Directive bears little resemblance to this ambitious plan.

The considerable pruning of the proposal is a reaction to the fierce criticism provoked by the Commission's original plan. Critics feared, in particular, that the planned full harmonisation of some parts of sales law would have far reaching and rather unpredictable consequences (so-called

\footnotetext{
${ }^{1}$ See European Parliament P7_TA-PROV (2011) 6-23.

${ }^{2}$ Directive 2011/83/EU of 22.11.2011, OJ 2011 L 304/64.

${ }^{3}$ COM (2008) 614 final.

${ }^{4}$ COM (2004) 651 final; see also COM (2006) 744 final.
} 
'spill-over effects') for the general law of obligations of the Member States. The envisaged full harmonisation of the rules on unfair contract terms also received considerable criticism. As a result, the text now adopted is lacking the two chapters on consumer sales and unfair terms. In addition, Art 3 Para 5 proposal now makes clear that the Directive shall not affect national general contract law.

Furthermore, the scope of the Directive has been reduced during the legislative process. From a systemic point of view, the exclusion of 'social services' (Art 3 Para 2 lit a) is of particular interest. This exception covers inter alia social housing, childcare and support of families and persons permanently or temporarily in need, including long-term care. Neither the Doorstep Selling Directive, nor the Distance Selling Directive currently contains such an exception. The provision is apparently inspired by Art 2 Para 2 lit j Services Directive 2006/123/EC. However, in the Services Directive the exception only applies to social services 'provided by the State, by providers mandated by the State or by charities recognised as such by the State'. This shows that Art 2 Para 2 lit $\mathrm{j}$ Services Directive is mainly based on sociopolitical considerations and aims at excluding the so-called 'third sector' from the market liberalisation policy pursued by the Internal Market and Services Directorate General. Within the structure of European consumer law, however, the notion of 'social services' is a novelty. The exclusion of such services which, not least for demographic reasons, are becoming a more and more important market is not very convincing. This applies particularly to the extension of this exclusion to private providers of social services as mentioned explicitly in Recital 29 Directive. It is not clear why the consumer protection rules of the new Directive should not apply to babysitting or nursing services offered at the doorstep or via the internet.

After the deletion of the originally planned provisions on consumer sales and control over unfair terms, the text adopted by the European Parliament is now more or less limited to a revision of the rules on information duties and rights of withdrawal for doorstep selling and distance selling (Art 6 et seqq proposal). Consequently, the Directives 87/577/EEC and 97/7/EC will be repealed (Art 31). The most salient changes in the field of doorstep and distance contracts include a unification of the rules regarding the length (now 14 calendar days) as well as the beginning and the calculation of the withdrawal period. In addition, the proposal now contains model instruction on withdrawal (Annex I.A.) and a model withdrawal form (Annex I.B.). The sanctions applicable if the consumer has not been informed about the right of withdrawal have also been revised. While the CJEU in the Heininger case ${ }^{5}$ acknowledged an 'eternal' right of withdrawal, the Distance Selling Directive only provided for an

${ }^{5}$ CJEU 13.12.2001 case C-481/99 (Heininger). extension of the withdrawal period of up to three months. The new proposal now introduces a common solution for both scenarios: If the consumer is not informed about the right of withdrawal, the withdrawal period is extended by 12 months (Art 10 Para 1). If, however, the business corrects this omission, the withdrawal period expires 14 days after the information on withdrawal rights has been provided (Art 10 Para 2). The list of exceptions from the right of withdrawal (Art 16) is less convincing. The lack of any systematic approach is shown e.g. by the exception for alcoholic beverages the price of which has been agreed upon at the time of the conclusion of the sales contract, the delivery of which can only take place after 30 days and the actual value of which is dependent on fluctuations in the market. Recital 49 proposal, which explicitly refers to 'vin en primeur', reveals that this provision may be the result of successful lobbying.

Practically unchanged as compared to the original proposal is Art 5, which contains a list of pre-contractual information requirements applicable to consumer contracts regardless of the object of the contract and situation in which the contract has been concluded. This provision considerably extends the European model of consumer protection through information by detaching it from its situational and substantive preconditions. Considering the growing criticism of the European 'information model' - not least from the perspective of behavioural economics - this is a rather questionable choice. Further criticism was sparked by further technical deficiencies in the information requirements: While Art 6 Para 9 places the burden of proof for fulfilling the information requirements on the trader in relation to doorstep and distance contracts, the general provision of Art 5 lacks such a rule. Yet it is hard to find a justification for treating the two cases differently. It is not entirely clear whether the information requirements set out in the Directive are meant to be exhaustive. According to Art 5 Para 4, Member States 'may adopt or maintain additional pre-contractual information requirements for contracts other than off-premises or distance contracts'. Taken literally, this provision e contrario seems to prohibit Member States from extending the information requirements for doorstep and distance contracts based on general principles of contract law (e.g. Treu und Glauben, good faith, bonne foi).

Under the heading "Other consumer rights", chapter IV of the proposal (Art 17 et seqq) brings together a somewhat random assortment of individual rules - some of which are recognisable as the remnants of the originally planned and more extensive set of provisions on consumer sales. For example, Art 18 contains a provision on the time of delivery of goods. Thus, where the trader has failed to fulfil his obligation to deliver at the agreed time, the consumer is entitled to terminate the contract after setting an additional period for performance (Art 18 Para 2). It is striking that this right 
to terminate, unlike that under Art 49 Para 2 CISG, is not subject to any time limit.

The Commission's original plan to introduce a broad regime of full harmonisation in the field of Consumer Law is now compromised in a number of cases. For example, the sanctions in case of breach of the information duties are mainly left to the Member States (Art 5). The same applies to the effects of the exercise of the right of withdrawal on ancillary contracts (Art 15 Para 2) as well as the remedies of the consumer in case of late delivery (Art 18 Para 2).

The fate of the Directive mirrors the frequently changing tides of European consumer policy during the last few years. After it had become obvious that the policy of minimum harmonisation does not lead to the creation of common rules for the Internal Market, the original proposal submitted by the Commission intended to introduce a shift from sector-specific minimum harmonisation to horizontal full harmonisation. After a tenacious political struggle, the Commission's proposal has been reduced to its bare bones. The Directive thus symbolises another change of direction in the development of European consumer contract law. Instead of harmonising the laws of Member States, the Commission now favours complementing national laws by a genuinely European contract law, as the vigour shown by the Commission in preparing an Optional Instrument illustrates. Apparently, the aim is no longer 'harmonisation' but 'complementation'.

\section{The regulation on a common european sales law: who is afraid of the 'Blue Button'?}

On October 2011, the European Commission presented the much-awaited proposal for a regulation on a common European Sales Law, better known as the "Optional Instrument". ${ }^{6}$ The substance of the proposal more or less corresponds to the feasibility study published in May 2011 by the Commission's Expert Group. ${ }^{7}$ The publication of the draft Regulation marks the provisional climax of a development stretching from the Principles of European Contract Law (PECL), over the Draft Common Frame of Reference (DCFR), to the new legislative proposal. It also marks the beginning of a new debate on the future of European Contract Law. A detailed analysis of the proposed rules would exceed the scope of this short legislation report. Therefore, the focus of this preliminary assessment will lie on some of the key policy decisions underlying the proposal which, together with some of the more technical details, most likely will be at the heart of the forthcoming debate.

\footnotetext{
${ }^{6}$ COM (2011) 635 final.

${ }^{7}$ The Expert Group was set up by Commission Decision 2010/233/EU of 26.04.2010, OJ 2010 L 105/109.
}

The Commission's proposal consists of two parts: A draft Regulation comprising only 15 articles, which mainly set out the scope of application of the new EU sales law, as well as an annex of 184 articles containing the substantive provisions of the Common European Sales Law (CESL). The proposal aims at creating a "comprehensive set of uniform contract law rules covering the whole life-cycle of a contract" which shall exist as a "second regime of contract law" alongside the national laws of the Member States. ${ }^{8}$ The CESL only applies if the parties agree that the new rules shall govern their contract (Art 3 Draft Regulation). The Commission emphasizes that an agreement to use the CESL should "not amount to, and not be confused with, a choice of the applicable law within the meaning of the conflict-of-law rules". ${ }^{9}$ This somewhat opaque wording is apparently meant to express that the Commission has opted for a uniform law approach, i.e. establishing the CESL outside the system of the Rome I Regulation.

The scope of application of the CESL is limited in several respects. According to Art 4 Draft Regulation, a choice of the optional contract law is only possible for cross-border contracts. This limitation seems to reflect certain doubts regarding the legislative competence of the EU for creating a contract law applicable also for purely domestic situations. However, Art 13 provides for an option which explicitly allows Member States to extend the scope of the CESL to domestic contracts. Strictly speaking, this provision is redundant, as Member States would have the freedom to do so anyway. From this perspective, Art 13 seems to be a politically motivated invitation for the Member States to make use of this option.

According to Art 5 of the Draft Regulation, the substantive scope of the CESL is limited to sales contracts, contracts for the supply of digital content and related service contracts. Judging from the wording of this provision, it is unclear whether the CESL is also applicable to cloud computing services which do not involve any "supply" of digital content but only provide access e.g. to music files stored on a remote server. Considering the growing importance of such services, the inclusion of cloud computing services ought to have been made explicit. In contrast, the optional regime may not be used for other common cross-border contracts, such as leasing or franchising contracts, nor for any mixed-purpose contracts. This is a regrettable, yet understandable limitation. It would not have been a wise decision to overburden the first draft of an optional contract law with a multitude of specific provisions for different types of contracts. It is to be welcomed, however, that most parts of the

\footnotetext{
${ }^{8}$ Commission Communication, A Common European Sales Law to facilitate cross-border transactions in the Single Market, COM (2011) 636,7 .

${ }^{9}$ Recital 10 Draft Regulation, COM (2011) 635.
} 
CESL - except Parts IV and V - are drafted in a way which allows for extending the rules to other types of contracts without too much difficulty.

The scope of application of the CESL is also limited with regard to the parties who may choose it. Rather unusual in this context is Art 7 Para 1 Draft Regulation which stipulates that in $\mathrm{B} 2 \mathrm{~B}$ relations, the CESL may only be used if at least one of the parties is a small or medium-sized enterprise (SME). For the purpose of this provision an SME is a business which employs less than 250 persons and which has an annual turnover not exceeding EUR 50 million or an annual balance sheet total not exceeding EUR 43 million (Art 7 Para 2 Draft Regulation). Regardless of the more general question whether it is a reasonable policy choice to create a specific contract law for SMEs, this approach creates legal uncertainty in the B2B market: In future, parties may have to enquire about the number of employees of their potential contracting partner in order to know which contract regime they may choose. In addition, the draft Regulation disadvantages successful and growth-oriented SMEs selling to other businesses: The more successful they are, the sooner they will grow out of the field of application of the CESL.

The substantive provisions of the CESL are marked by a comparatively high level of consumer protection. ${ }^{10}$ For example, in case of non-conformity of the goods, the consumer may immediately terminate the contract unless the lack of conformity is insignificant (Art 106 Para 1 lit c, Art 114 Para 2). In other words, the consumer is not obliged to accept the seller's offer to cure the non-conformity. Another example of the consumer friendly approach taken by the CESL is Art 45 Para 4. According to this provision, the consumer is not liable to pay any compensation for the use of the goods during the withdrawal period. This provisions deviates from the rule set up by the CJEU in the "Messner" case. ${ }^{11}$ There, the Court decided that the consumer had to compensate the business where he had made use of the goods "in a manner incompatible with the principles of civil law, such as those of good faith or unjust enrichment". The solution adopted by the CESL is not only more consumer friendly, it also creates more legal certainty.

The analysis and evaluation of the Commission's proposal has just started. Yet the first reactions show that there will be a passionate debate. The Bureau Européen des Unions des Consommateurs (BEUC) has fiercely criticised the proposal, whereas the British Federation of Small Businesses (FSB) and the German Federal Chamber of Lawyers (BRAK) have welcomed it.

\footnotetext{
${ }^{10} \mathrm{Cf}$ the article by Zoll (in this issue).

${ }^{11}$ CJEU 03.09.2009 case C-489/07 (Messner).
}

\section{The regulation on the provision of food information to consumers: mandatory information and delegated legislation}

A reform of consumer law is also under way in the field of food information. After more than three years of negotiations, the Member States reached a compromise in June 2011 in the Committee of Permanent Representatives on the reform of food labelling rules. In early July 2011, the European Parliament gave its approval. The Council has given its formal consent to the new Regulation on the provision of food information to consumers (RFIC) on 29.09.2011.

The new Regulation, which aims at providing better food information to consumers, replaces inter alia the existing Food Labelling Directive 2000/13/EC and the Nutrition Labelling Directive 90/496/EEC. The main changes - apart from the shift from Directives to Regulation - include stricter rules for nutrition labelling, information on substances with allergenic effect and the indication of the country of origin or the place of provenance. The majority of the new rules will only apply after a three year transitional period. For the new rules on nutrition labelling a five year transitional period will apply.

During the negotiations on the new Regulation, the introduction of mandatory nutrition labelling was a particularly controversial issue. Generally speaking, EU law currently does not require producers to provide information about the nutritional content of their products. Those producers who choose to do so, on a voluntary basis, are only obliged to comply with certain rules regarding the presentation of such information (Arts 2 and 4 Directive 90/946/EEC). The new Regulation now requires a table with mandatory information on the energy value and six nutrients (fat, saturates, carbohydrate, sugars, protein and salt) (Art 30 Para 1 RFIC). In order to ensure the comparability of the nutrition information, the declaration has to refer to units of 100 grams or 100 millilitres. Additional information on nutrients per serving is allowed. In contrast, the proposal to introduce a colour-coded nutrition labelling scheme ("traffic light scheme") was rejected.

Particular labelling requirements will apply for so-called food imitation products (e.g. substitute cheese). The substitute component has to be indicated in immediate proximity to the product name. The font size used for the declaration of the substitute has to be $75 \%$ of the size used for the product name (Annex VI No 4). Meat products which may give the impression that they are made of a whole piece of meat or fish, but actually consist of different pieces combined together have to be labelled as "formed meat" (Annex VI No 7). These provisions are complemented by Art 7 Para 1 lit $\mathrm{d}$ according to which food information must not be misleading by suggesting the presence of a particular food or an ingredient, while in reality a component naturally present or 
an ingredient normally used in that food has been substituted with a different component or a different ingredient.

The new Regulation also extends the information requirements on ingredients that may cause allergic reactions. Potential allergens have to be highlighted in the list of ingredients, e.g. by means of a specific background colour (Art 21 RFIC). In addition, mandatory allergen labelling requirements that currently only apply to pre-packaged food (Art 6 Para 1 and Annex IIIa Directive 2000/13/EC) will be extended to food which is not pre-packaged. However, the Member States are left to decide upon the wording of such a declaration (Art 44 Para 2 RFIC).

A salient point which is also of particular interest beyond the field of food law is the far-reaching authorisation of the Commission to adopt delegated acts under Art 290 TFEU and implementing acts under Art 291 TFEU in connection with the new Regulation 182/2011/EU. Here, the new Regulation makes use of the new rules on comitology as revised by the Lisbon Treaty. This mechanism shall ensure the adaptability and flexibility of the new information requirements for foodstuffs. It will be interesting to observe whether this multi-level legislative approach, which could serve as a model for other information duties in the field of consumer law, will prove workable.

\section{The directive on credit agreements relating to residential property: a legal framework for responsible lending?}

The inconsiderate granting of mortgage loans to un-creditworthy consumers was one of the causes of the financial crisis of 2008, the aftermath of which is still troubling the European Union. As a direct reaction to the crisis, the European Commission already promised in 2009 to elaborate a new legal framework for responsible lending and propose new rules for credit intermediaries. ${ }^{12}$ The draft for a Directive on credit agreements relating to residential property published in late March 2011 contains a proposal for such a set of rules. ${ }^{13}$ The new Directive shall both promote the Internal Market for mortgage loans and contribute to the stability of financial markets.

The proposal covers credit agreements secured by a mortgage or another comparable security, loans to purchase a property and certain credit agreements aimed at financing the renovation of a property (Art 2). For such agreements, the planned Directive imposes rather vaguely termed rules of conduct (Art 5) and defines minimum competence requirements for creditors and credit intermediaries (Art 6). In particular, Art 5 which lays down the duty to act 'honestly,

\footnotetext{
$\overline{{ }^{12} \text { COM (2009) }} 114$ final.

${ }^{13}$ COM (2011) 142 final.
}

fairly and professionally in accordance with the best interests of the consumer,' could create a considerable liability risk for creditors and credit intermediaries.

Extensive requirements for the pre-contractual phase form the centrepiece of the new Directive, which establishes a rather complex regime of information rules. All advertising for credit contracts has to contain a set of standard information (Art 8). These information duties complement and extend the rules set out in the Unfair Commercial Practices Directive 2005/29/EC. In addition, creditors and credit intermediaries are obliged to make general information available on the range of their credit products at all times (Art 9 Para 1). To this general product information personalised information is added, which the consumer needs in order to make an informed decision about entering into a credit contract (Art 9 Para 2). For this purpose the consumer is for his part obliged to disclose his personal and financial situation (Art 15). For the provision of the personalised information, the draft Directive contains a European Standardised Information Sheet (ESIS, Annex II). Additionally, further information duties apply to credit intermediaries (Art 10), which inter alia aim at increasing the transparency of possible conflicts of interest.

These requirements are not entirely new, but some of them deviate from the model set by the Consumer Credit Directive 2008/48/EC without indicating in all cases an objective justification. In addition, pre-contractual information duties are already imposed by the European agreement on a voluntary code of conduct on pre-contractual information for home loans ${ }^{14}$ from 05.03.2001 and Recommendation $2001 / 193 / \mathrm{EC}^{15}$. In practice these 'soft' European rules are not sufficiently complied with. Therefore, the Commission has now set up mandatory rules. The introduction of a standardised information sheet, which may also contribute to the overcoming of language barriers, is to be welcomed. Shortcomings, however, exist with regard to the legal consequences of breaching the rules. Art 24 Para 1 only provides for administrative sanctions. The proposal is silent on private law instruments for consumer protection such as a right of withdrawal, which would easily fit into the system of European Contract Law. ${ }^{16}$

The provisions on the creditworthiness assessment of the consumer (Art 14) are a further core element of the planned Directive which are meant to prevent the irresponsible gran-

\footnotetext{
${ }^{14}$ Available at $<$ ec.europa.eu/internal_market/finservices-retail/docs/ home-loans/agreement_en.pdf $>$.

${ }^{15}$ Commission Recommendation 2001/193/EC of 01.03.2011 on precontractual information to be given to consumers by lenders offering home loans, OJ 2001 L 69/25.

${ }^{16}$ See also the European Central Bank Opinion CON/2011/58 of 05.07.2011 on a proposal for a directive of the European Parliament and of the Council on credit agreements related to residential property, OJ 2011 C 240/3.
} 
ting of subprime credit. This provision could also turn out to be a liability trap for creditors and credit intermediaries. If, for example, a bank has wrongfully provided a positive creditworthiness assessment to a consumer, this could possibly be seen as a breach of a 'duty to protect' which could give rise to liability.

In addition, the proposal regulates the right of the consumer to repay the mortgage debt early for the first time (Art 18). However, it is for the Member States to set out under which conditions this right may be exercised, e.g. subject to a prepayment penalty.

The rules set out above are complemented by regulatory requirements regarding the authorisation, registration and supervision of credit intermediaries (Art 19-22). Further changes concern the calculation of the annual percentage rate of charge (Art 12 in connection with Annex II), which follows the model set by Directive 2008/48/EC, as well as the introduction of out-of-court dispute resolution mechanisms (Art 25).

From a more general point of view, the far reaching authority granted by the Directive to the Commission to enact delegated acts is particularly interesting. Thus, the Commission is authorised under Art 9 Para 3 to adapt the pre-contractual information duties and change both the content and form of the Standardised Information Sheet (ESIS). This seems to show a looming trend towards a flexible blueprint for consumer protection rules. It is still too early to tell whether the detailed procedural rules for the exercise of the delegation (Art 26 et seq) will be able to ensure a reasonable balance between flexible amendment of the law and parliamentary legitimacy. 